\title{
NOTES
}

\section{JUDICIAL REVIEW UNDER COMPLETE AUTO TRANSIT: WHEN IS A STATE TAX ON ENERGY-PRODUCING RESOURCES "FAIRLY RELATED"?}

State taxes levied on goods moving in imterstate commerce bring into conflict two fundamental legal doctrines. On the one hand is the state's constitutional right to levy taxes in support of valid state interests - a basic tenet of federalism. ${ }^{1}$ In opposition to that right, however, stands the commerce clause ${ }^{2}$ and its implicit commitment to unobstructed trade among the states. ${ }^{3}$

This clash between state taxing power and the commerce clause encompasses all taxes affecting goods within the stream of interstate commerce-a vast body of law. However, recent fuel production and energy conservation concerns liave highlighted a subissue of growing importance: a state's right to tax energy-producing natural resources located within its borders. ${ }^{4}$ The current trend among resource-rich states toward substantially increased taxation of their energy-producing

1. See, e.g., Boston Stock Exch. v. State Tax Comm'n, 429 U.S. 318, 328-29 (1977); Wisconsin v. J. C. Penney Co., 311 U.S. 435, 444 (1940); Postal Tel.-Cable Co. v. City of Richmond, 249 U.S. 252, $257-59$ (1919); Case of the State Freight Tax, 82 U.S. (15 Wall.) 232, 272 (1872).

2. "The Congress shall have Power . . . To regulate Commerce with foreign Nations, and among the several States, and with the Indian Tribes . . .."U.S. CoNST. art. I, \& 8, cl. 3.

3. "[T]he Commerce Clause ... created an area of trade free froin interference by the States." Freeman v. Hewit, 329 U.S. 249, 252 (1946). See West v. Kansas Natural Gas Co., 221 U.S. 229, 255 (1911); J. NowAK, R. RotundA \& J. Nelson, HANDBOOK ON Constitutional LAW 128-29 (1978) [hereinafter cited as J. Nowak]; Browde \& DuMars, State Taxation of Natural Resource Extraction and the Commerce Clause: Federalism's Modern Frontier, 60 OR. L. REv. 7, 12 (1981).

4. See, eg., Browde \& DuMars, supra note 3, at 7; J. Hellerstein, State Taxation Under the Commerce Clause: An Historical Perspective, 29 VAND. L. REv. 335 (1976); W. Hellerstein, State Taxation in the Federal System: Perspectives on Louisiana's First Use Tax on Natural Gas, 55 TuL. L. REv. 601 (1981) [hereinafter cited as W. Hellerstein, First Use Tax]; W. Hellerstein, Constitutional Constraints on State and Local Taxation of Energy Resources, 31 NAT'L TAX. J. 245 (1978) [hereinafter cited as W. Hellerstem, Constitutional Constraints]; Lockhart, A Revolution in State Taxation of Commerce?, 65 MiNN. L. REv. 1025 (1981); Madere, State Taxation After Mobll and Exxon, 33 TAX EXECUTIVE 103 (1981). 
resources ${ }^{5}$ and the concomitant influx of billions of tax revenue dollars into state coffers ${ }^{6}$ at the expense of nonresident energy consumers necessitates a judicial resolution of this subissue. ${ }^{7}$

In Complete Auto Transit, Inc. v. Brady the Supreme Court devised a four-prong test by which to evaluate state taxes challenged under the commerce clause. The Court held that a tax is constitutional if it "is applied to an activity with a substantial nexus with the taxing State, is fairly apportioned, does not discriminate against interstate commerce, and is fairly related to the services provided by the State."9 Later, in Commonwealth Edison Co. $v$. Montana, ${ }^{10}$ the Court interpreted the fourth prong of this test, the "fairly related" element, to require only that the tax be "assessed in proportion to a taxpayer's activities or presence in a State." 11 Thus, the tax must be fairly related only to the taxpayer's contact with the state, not to the value of the services provided by the state.

'This note examines the Commonwealth Edison Court's interpretation of the "fairly related" standard and the resulting diminution in the scope of the commerce clause. First, the note sketches the evolution of the Court's policy toward state taxation of interstate commerce. ${ }^{12}$ The note then criticizes on both theoretical and practical grounds the Court's mismterpretation of the "fairly related" standard. ${ }^{13}$ Finally, the note proposes a workable method for

5. See Browde \& DuMars, supra note 3, at 7; Church, Conficting Federal, State and Local Interest Trends In State and Local Energy Taxation: Coal and Copper - A Case in Point, 31 Nat'l TaX J. 269, 278 (1978); Link, Political Constraint and North Dakota's Coal Severence Tax, 31 NAT'L TAX J. 263 (1978); Lockhart, supra note 4, at 1045-59 and cases cited therein.

6. See, eg., Commonwealth Edison Co. v. Montana, 453 U.S. 609, 641 (1981) (Blackmun, J., dissenting) ("It has been suggested that by the year 2010, Montana will have collected more than $\$ 20$ billion through the implementation of this tax.").

Among the many other states enjoying substantial resource tax revenue are Alaska (\$29 million from a production tax on natural gas and oil, or $14 \%$ of its tax revenue), Louisiana ( $\$ 548$ million from a severence tax on natural gas and oil, or $36 \%$ of its tax revenue), Oklahoma ( $\$ 128$ million from a production tax on oil and natural gas, or 14.5\% of its tax revenue), and Texas ( $\$ 664$ million from a severance tax on oil, natural gas and sulphur, or $18.3 \%$ of its tax revenue). T. Stinson, State Taxation of Mineral Deposits and Production 20, 25, 39, 41 (Jan. 1977) (prepared for partial fulfillment of EPA contract EPA 1A-G-D6-E766) (figures for the year 1975).

7. See Note, Commerce Clause Restraints on Stale Taxation of Energy Resources: $A$ Suggested Framework for Analysis, 60 WASH. U.L.Q. 425 (1982).

8. 430 U.S. 274 (1977).

9. Id. at 279 (einphasis added).

10. 453 U.S. 609 (1981).

11. Id. at 627 .

12. See infra notes $15-57$ and accompanying text.

13. See infra notes 58-111 and accompanying text. 
determining whether a state's taxes are in fact "fairly related to the services provided." 14

\section{Development of States' Right to Tax Interstate COMMERCE}

The modern paraineters of a state's right to tax interstate cominerce evolved from more than a century of Supreme Court decisions. Until recently, however, these parameters had not been well defined, in part because of the Court's frequent modifications of the principles from which they were derived. A brief review of the traditional doctrine provides helpful background to the inost recent change in those standards, as set forth in Complete Auto Transit, Inc. v. Brady in 1977.15

In 1872 the Supreme Court established the basis for what has become known as the traditional, or fornal, ${ }^{16}$ approach to the states' right to tax interstate commerce. In Case of the State Freight Tax, ${ }^{17}$ the Court held that a tax on the physical movement of interstate freight through the taxing state was "in effect a regulation of interstate cominerce"18 and thus a violation of the commerce clause. ${ }^{19}$ The decision unequivocally prohibited all state taxes affecting interstate commerce, thus resolving the conflict between the commerce clause and a state's taxing power decidedly in favor of unfettered interstate trade.

This unqualified support of the commerce clause was short-lived, however. ${ }^{20}$ Gradually, the Court adopted the position that certain aspects of interstate business were so intrinsic to their places of occurrence as to be mere "local incidents" of that business. ${ }^{21}$ Taxes were not

14. See infra notes $112-22$ and accompanying text.

15. 430 U.S. 274 (1977). The following discussion parallels that found in Browde \& DuMars, supra note 3, at 10-13; W. Hellerstem, State Taxation and the Supreme Court: Toward a More Unified Approach to Constitutional Adjudication? 75 MicH. L. REv. 1426, $1441-45$ (1977) [hereinafter cited as W. Hellerstein, State Taxation and the Supreme Court]; and Lockhart, supra note 4, at $1027-30$.

16. Lockhart, supra note 4 , at 1027.

17. 82 U.S. (15 Wall.) 232 (1872).

18. Id.

19. Id. at 281. "[W]e regard it as established that no State can impose a tax upon freight transported from State to State, or upon the transporter because of such transportation." Id. at 281-82.

20. Supreme Court decisions following the strict interpretation of Case of the State Freight Tax were limited to the twenty years following that decision. See Atlantic \& Pac. Tel. Co. v. Philadelphia, 190 U.S. 160 (1903); Leloup v. Port of Mobile, 127 U.S. 640 (1888); Fargo v. Michigan, 121 U.S. 230 (1887); Robbins v. Shelby Taxing Dist., 120 U.S. 489 (1887); Pickard v. Pullman S. Car Co., 117 U.S. 34 (1886); Gloucester Ferry Co. v. Pennsylvania, 114 U.S. 196 (1885); Moran v. New Orleans, 112 U.S. 69 (1884); Telegraph Co. v. Texas, 105 U.S. 460 (1881); Pensacola Tel. Co. v. Western Umion Tel. Co., 96 U.S. 1 (1877).

21. See Umited States v. E.C. Knight Co., 156 U.S. 1 (1895); Browde \& DuMars, supra note 3 , at 34 . 
subject to commerce clause scrutiny, therefore, if they were directed toward events that preceded interstate commerce and thus were not yet within the constitutionally-protected streain of commerce. ${ }^{22}$ In keeping with this distinction between the local and interstate aspects of business, the Court struck down state taxes expressly levied on the privilege of doing business within that state (privilege taxes) because such taxes clearly were not imposed on a "local incident" of the business. ${ }^{23}$ Not surprisingly, courts often had difficulty distinguishing local and nonlocal incidents, ${ }^{24}$ thereby creating uncertainty as to when a tax was in fact levied on the privilege of doing business. As a consequence, courts increasingly rehed on arbitrary classifications of taxes, frequently favoring form over substance with respect to their constitutionality. ${ }^{25}$

State taxes also were upheld on the alternate rationale that "[e]ven interstate business inust pay its way."26 In Western Live Stock v. Bureau of Revenue, the Supreme Court stated that "[i]t was not the purpose of the commerce clause to relieve those engaged in interstate commerce froin their just share of state tax burden even though it increases the cost of doing the busmess." 27 The Court thus retreated further froin its earlier doctrine of strict immunity froin state taxation of interstate commerce and exacerbated the uncertainty surrounding the constitutionality of such a tax. The confusion peaked in Colonial Pipe-

22. Browde \& DuMars, supra note 3, at 34. See, e.g., Memphis Natural Gas Co. v. Stone, 335 U.S. 80 (1948); Coverdale v. Arkansas-Louisiana Pipe Line Co., 303 U.S. 604 (1938); Utah Power \& Light Co. v. Pfost, 286 U.S. 165 (1932); Heisler v. Thomas Colliery Co., 260 U.S. 245 (1922); American Mfg. Co. v. St. Louis, 250 U.S. 459 (1919); United States v. E.C. Knight Co., 156 U.S. 1 (1895).

23. See, eg., Memphis Steam Laundry Cleaner v. Stone, 342 U.S. 389 (1952); Spector Motor Serv. v. O'Connor, 340 U.S. 602 (1951); Alpha Portland Cement Co. v. Massachusetts, 268 U.S. 203 (1925).

24. Postal Tel.-Cable Co. v. City of Richmond, 249 U.S. 252 (1919). Property, hicense, privilege and occupation (if levied on imtrastate activities), retail sales, net imcome, compensatory use, and gross income taxes all were held sufficiently indirect to pass constitutional muster, general privilege taxes were not. Lockhart, supra note 4, at 1030 and cases cited therein.

25. The Supreme Court acknowledged relatively early in the development of this area of law that confusion existed:

To attempt to harmonize all that has been said in the past would neither clarify what has gone before nor guide the future. Suffice it to say that especially in this field opinions must be read in the setting of the particular cases and as the product of preoccupation with their special facts.

Freeman v. Hewit, 329 U.S. 249, 252 (1946). See generally Browde \& DuMars, supra note 3, at 34; W. Hellerstem, State Taxation and the Supreme Court, supra note 15, at 1443-44. Also, compare the progressively strained logic of Spector Motor Serv., Inc. v. O'Connor, 340 U.S. 602 (1951), Northwestern States Portland Cement Co. v. Minnesota, 358 U.S. 450 (1959) and Colonial Pipeline Co. v. Traigle, 421 U.S. 100 (1975).

26. Postal Tel.-Cable Co. v. City of Richmond, 249 U.S. 252, 259 (1919).

27. 303 U.S. 250, 254 (1938); see Freeman v. Hewit, 329 U.S. 249, 253 (1946). 
line Co. v. Traigle, ${ }^{28}$ in which a previously invahdated tax was held constitutional after a state legislature merely changed the official description of the tax from that of a "privilege" tax to one covering "[t]he qualification to carry on or do busmess in this state or the actual doing of business within this state in a corporate form."29

In 1977, the Court abandoned the formalistic analysis used in $\mathrm{Co}$ lonial Pipeline and articulated a four-prong test to determine the constitutionahity of a state tax on interstate commerce. The decision in Complete Auto Transit, Inc. v. Brady ${ }^{30}$ upheld a Mississippi sales tax specifically characterized as a "privilege [tax] for the privilege of . . . doing business within this state,"31 expressly rejecting the traditional doctrine on which the plaintiff taxpayers relied. ${ }^{32}$ The Court held that a tax will survive a commerce clause challenge if it is "applied to an activity with a substantial nexus with the taxing State, is fairly apportioned, does not discriminate against interstate commerce, and is fairly related to the services provided by the State." 33 In theory, the Court completely reversed its approach to a state's right to tax interstate commerce. Yet in practice, the Court inerely abandoned exphicitly a doctrine it had ceased to support years earher. ${ }^{34}$ No longer must courts determine whether a tax is levied on goods prior to their entering the stream of commerce ${ }^{35}$ or whether it is a forbidden "privilege" tax. ${ }^{36}$
28. 421 U.S. 100 (1975).
29. Id. at 103.
30. 430 U.S. 274 (1977).
31. Miss. Code ANn. § 27-65-13 (1972):

There is hereby levied and assessed, and shall be collected, privilege taxes for the privilege of engaging or continuing in business or doing business within this state to be determined by the application of rates against gross proceeds of sales or gross income or values, as the case may be, as provided in the following sections.

32. "Under the present state of the law, the Spector rule, as it has come to be known, has no relationship to economic realities. Rather it stands only as a trap for the unwary draftsman." 430 U.S. at 279.

The traditional doctrine was most clearly articulated in Spector Motor Serv., Inc. v. O'Connor, 340 U.S. 602 (1951), which declared unconstitutional a state tax on the "privilege of doing business" within the state by a company engaged exclusively in interstate commerce. The decision focused solely on the incidence of the corporate net income tax, ignoring its practical effects. "This fornalistic application of the privilege doctrine virtually determined the validity of a particular tax according to the name the state legislature gave it." Browde \& Du Mars, supra note 3 , at 34 .

33. 430 U.S. at 279.

34. See supra notes 24-29 and accompanying text.

35. See supra note 22 and accompanying text.

36. See supra note 23 and accompanying text. 
This, in turn, frees the states to compel interstate commerce to "pay its own way" without resorting to surreptitious statutory draftsmanship. ${ }^{37}$

The Supreme Court's most recent application of the Complete Auto Transit test in Commonwealth Edison Co. v. Montana ${ }^{38}$ is its only decision directly addressing the nature of the inquiry to be made when a state tax is challenged specifically as a violation of the "fairly related" requirement. Although previous Supreme Court decisions, weighed the test's. first three elements, they failed to consider the quantitative correlation between taxes paid and services provided: the Court either did not reach the fourtl prong issue, or addressed it incompletely, deciding only whether any service actually existed for which the state could tax. ${ }^{39}$ The Court has defined a universe of compensable state services, however, broadly stating that such services "include not only police and fire protection, but also the benefits of a trained work force and the advantages of a civilized society." 40 Yet, the plaintiffs in Commonwealth Edison posed a more specific question: must the taxes paid be fairly related to the value of the services provided?

Commonwealth Edison involved a Montana severance tax imposed on the contract sales price of coal mined within the state. ${ }^{41}$ Although a moderate severance tax had been in effect since 1921, the plaintiffs ${ }^{42}$ challenged the tax only after the Montana legislature substantially increased that tax in 1975, imposing an effective rate of up to thirty percent of the statutorily-defined sales price in certain circuinstances. ${ }^{43}$ Plaintiffs sued to recover taxes paid under protest, claiming that the tax violated the commerce clause as interpreted in Complete Auto Transit.44 The Montana Supreme Court, affirming a lower court opimion, held

37. For examples of such draftsmanship, see Colonial Pipeline Co. v. Traigle, 421 U.S. 100, 103 (1975), and Spector Motor Serv., Inc. v. O'Connor, 340 U.S. 602, 603 n.1 (1951). See supra notes 28-29 and accompanying text.

38. 453 U.S. $609,620-29$ (1981).

39. The parties in Complete Auto Transit did not dispute the challenged tax's relation to benefits provided by the state. 430 U.S. at 287. In Mobil Oil Corp. v. Commissioner of Taxes, 445 U.S. 425 (1980), the Court held, without addressing the fourth prong of Complete Auto Transit, that a Vermont income tax was not unconstitutional multiple taxation. See also Exxon Corp. v. Department of Revenue, 447 U.S. 207, 228 (1980); Japan Line v. County of Los Angeles, 441 U.S. 434, 445 (1979); Department of Revenue v. Association of Wash. Stevedoring Cos., 435 U.S. 734, $750-51$ (1978).

40. Japan Line v. Connty of Los Angeles, 441 U.S. 434, 445 (1979).

41. Mont. Code ANN. $\$ \S 84-1312$ to 1325 (Supp. 1977).

42. The plaintiffs were eleven out-of-state utility conpanies and four Montana coal producers. 453 U.S. at 613.

43. Id.

44. Plaintiffs also claimed that the Montana tax was inconsistent with the Mineral Lands Leasing Act of 1920, ch. 85, 41 Stat. 437 (codified as amended in scattered sections of 30 U.S.C.), and that it frustrated national energy policies, in violation of the supremacy clause of the United States Constitution, U.S. CoNST. art. VI, \& 2. After analyzing the relevant federal statutes in light of Montana's taxing power, the Court concluded that the tax did not violate the supremacy clause. 
alternatively that (1) the severance tax was levied on goods prior to their entering the stream of interstate commerce ${ }^{45}$ and thus was not subject to Complete Auto Transit analysis, or (2) the tax survived scrutiny under the Complete Auto Transit test. ${ }^{46}$ The United States Supreine Court expressly rejected the state court's conclusion that application of Complete Auto Transit depends upon a vague determination of the time at which goods enter the stream of commerce. 47 The Court held, however, that the tax satisfies the Complete Auto Transit test and thus is consistent with the commerce clause. 48

In determining that Montana's coal severance tax is "fairly related to the services provided by the State," the Court einployed a three-step analysis. First, it stressed that states have a fundamental right to tax to raise revenues and to recover from imterstate commerce its "just share of the state tax burden." 49 The Court noted that "there is no requirement under the due process clause that the amount of general revenue taxes collected from a particular activity must be reasonably related to the value of the services provided." It concluded, therefore, that "It] here is no reason to suppose that this latitude afforded the States under the due process clause is somehow divested by the commerce clause merely because the taxed activity has some connection to interstate commerce." 50

In the second step of its analysis, the Court construed the actual language of the "fairly related" requirement in light of past decisions.

45. Commonwealth Edison Co. v. Montana, 615 P.2d 847, 854 (1980). See supra note 22 and accompanying text; Hope Natural Gas Co. v. Hall, 274 U.S. 284 (1927); Oliver Iron Mining Co. v. Lord, 262 U.S 172 (1923); Heisler v. Thomas Colliery Co., 260 U.S. 245 (1922).

46. 615 P.2d at 856 .

47. "We agree that Heisler's reasoning has been undermined by more recent cases. . . The Court has . . . long simce rejected any suggestion that a state tax or regulation affecting interstate commerce is immune from Commerce Clause scrutiny because it attaches only to a 'local' or intrastate activity." Commonwealth Edison Co. v. Montana, 453 U.S. at 614-15. Thus, the Court overruled Heisler v. Thomas Colliery Co., 260 U.S. 245 (1922).

48. The Plaintiffs conceded that the tax satisfied the first and second prongs of the Complete Auto Transil test. 453 U.S. at 617 . The Supreme Court held that the tax was is discriminatory (the third prong) because it is computed at a single rate regardless of the coal's destination or the residence of the consumers. Id. at 617-20.

49. Id. at 623-24. See supra notes $26-27$ and accompanying text. The Court began by adopting the Montana Supreme Court's characterization of the tax as a "general revenue tax," instead of a "user tax," id. at 621-22, and based its subsequent analysis on that characterization.

50. 453 U.S. at 622-23. The Court also re-emphasized the breadth of the taxable services that a state may provide. Id. at 624 . See supra note 40 and accompanying text.

51. These past decisions include National Geographic Soc'y v. California Bd. of Equalization, 430 U.S. 551 (1977); Complete Auto Transit, Inc. v. Brady, 430 U.S. 274 (1977); General Motors Corp. v. Washington, 377 U.S. 436 (1964); Wisconsin v. J.C. Penney Co., 311 U.S. 435 (1940); Western Live Stock v. Bureau of Revenue, 303 U.S. 250 (1938). 
The Court concluded that the fourth prong is "closely connected to the first prong $52 \ldots$ [and merely] . . . imposes the additional limitation that the measure of the tax must be reasonably related to the extent of the contact . . . " 53 Therefore, the Court sees the fourth prong only as an extention of the first; not as a separate element of the test. The tax need merely be "assessed in proportion to a taxpayer's activities or presence in a State," 54 and need not be proportional to the value of the services provided.

Finally, the Court advanced a more practical justification for its decision. Because of the "difficulty of the judicial undertaking" and the "nature of the factfinding and judgment that would be required" to determine "the appropriate level of state taxes,"ss the Court opted to defer to the state legislatures' determination of the proper tax rate, and to Congress's ability to supervise those legislatures adequately in keeping with the dictates of the commerce clause. ${ }^{56}$ The political process was thus deemed the appropriate forum for resolving the issue. In the final analysis, it may be this fact-finding burden and the perceived superiority of the political process that most strongly influenced the Court to reject the quantitative method of judicial review proposed by the plaintiff taxpayers and this note. 57

\section{COMMONWEALTH EDISON'S MISINTERPRETATION OF THE FOURTH PRONG}

It is difficult to discern the nature of the fourth-prong imquiry Justice Blackmun intended when he authored the majority opinion in

52. The first prong requires that the tax be "applied to an activity with a substantial nexus with the taxing State." Complete Auto Transit, Inc. v. Brady, 430 U.S. at 279.

53. Commonwealth Edison Co. v. Montana, 453 U.S. at 625-26.

54. Id. at 627 .

55. Id. at 628. "II]t is doubtful whether any legal test could adequately reflect the numerous and competing economic, geographic, demographic, social, and political considerations that must inform a decision about an acceptable rate or level of state taxation, and yet be reasonably capable of application in a wide variety of individual cases." Id.

56. Id at 627.

57. The Commonwealth Edison decision was the product of a significantly divided Court, with six justices in the majority and three justices strongly dissenting. Justice White wrote a concurring opinion joining the inajority with some uncertainty:

This is a very troublesome case for me, and I join the Court's opinion with considerable doubt and with the realization that Montana's levy on consumers in other States inay in the long run prove to be an intolerable and unacceptable burden on commerce. Indeed, there is particular force in the argument that the tax is here and now unconstitutional. But... Congress lias the power to protect interstate commerce from intolerable or even undesirable burdens . . [ [and] Congress is so far content to let the matter rest. As I presently see it, therefore, the better part of both wisdom and valor is to respect the judgment of the other branches of the Government.

453 U.S. at 637-38 (White, J., concurring). One member of the majority, Justice Stewart, has since retired from the Court. 
Complete Auto Transit. The Court did not undertake a fourth-prong analysis in that case because the parties did not contest the issue. ${ }^{58}$ It seems likely that the Court's inclusion of the "fairly related" element in the test, apart from the "substantial nexus" first prong, indicates that the first and fourth prongs address different concerns. It is possible, however, that Justice Blackmun did not carefully consider the proper nature of mquiry to be inade under the fourth prong because it was unnecessary to his resolution of the issue. The opinion itself provides no clue. No decision prior to Commonwealth Edison addresses a direct allegation that a tax is unconstitutionally excessive. ${ }^{59}$ Therefore, an interpretation of the fourth prong requires an investigation of the basis for the Complete Auto Transit decision.

\section{A. The Constitutional Basis for the Coinplete Auto Transit Test}

The constitutionality of a state tax on interstate commerce depends on a balancing of the state's right to raise revenues by taxation against the national interest in a free flow of goods among the states. 60 This conflict is implicit in the Complete Auto Transit test. The test first assumes the right to tax and then imposes constitutionally mandated limitations on that right. It is important to note, however, that these limitations derive from two discrete provisions of the Constitution the commerce clause ${ }^{61}$ and the due process clause ${ }^{62}$ - whicl have different purposes. In effect, the Court in Commonwealth Edison relied exclusively on a due process analysis of the Complete Auto Transit test, ${ }^{63}$ thereby ignoring the distinct purpose and indispensable safeguards of the commerce clause.

The commerce clause reflects the desire of the Founding Fathers to ensure adequate domestic narkets for goods and services in light of the problems created by the absence of such a provision in the Articles of Confederation. ${ }^{64}$ Although the Supreme Court's view of the extent of perinissible state actions lias varied over time, ${ }^{65}$ the underlying objective - prevention of unnecessary interference with free trade ainong the states - has reinained constant. ${ }^{66}$ Because a state tax on goods in

58. Complete Auto Transit, Inc. v. Brady, 430 U.S. at 287. See supra note 39.

59. See supra note 39 and accompanying text.

60. See supra text accoinpanying note 3 .

61. U.S. ConsT. ant. I, \& 8, cl. 3. See supra note 2.

62. "[N]or shall any State deprive any person of life, liberty, or property, without due process of law . . . ." U.S. CoNST. amend. XIV, § 1 .

63. See supra text accoinpanying notes 49-54.

64. J. Nowak, supra note 3, at 132-33; Browde \& DuMars, supra note 3, at 11.

65. J. NowAK, supra note 3, at 134-56. See supra text accompanying notes 16-37.

66. See supra note 3. 
interstate commerce is an interference, ${ }^{67}$ it requires scrutiny under the commerce clause. In contrast, the purpose of the due process clause is to protect the individual's right to life, liberty and property, ${ }^{68} \mathrm{a}$ concern inore closely related to fundamental human rights than to economic efficiency. Thus, although both the due process and commerce clauses require taxes affecting interstate commerce to be related in some manner to state-provided services, they do so in order to achieve different goals.

The existence of separate constitutional provisions and purposes should not lead to the conclusion reached in Commonwealth Edison that both clauses require the same relationship between the tax and the service provided. ${ }^{69}$ Indeed, the opposite is implied. The due process component of the Complete Auto Transit test is merely procedural, ${ }^{70}$ requiring that there be "certain minimum contacts" between the activities of the taxpayer and the taxing state. ${ }^{71}$ The first and second prongs adequately preserve due process by stating that the tax must be "applied to an activity with a substantial nexus with the taxing State" and must be "fairly apportioned."72 Commerce clause concerns, however, necessitate a different kind of inquiry and a closer relationship between taxes and benefits if the goals of the Founding Fathers are to be achieved. A tax that passes the due process test but is extremely burdensome can be at least as detrimental to free interstate trade as a modest tax levied on goods lacking a substantial nexus with the taxing state. The commerce clause, therefore, must impose restrictions on states' power to tax in addition to those required by due process. Complete

67. See generally P. Samuelson, Economics 388-99 (10th ed. 1976); Developments in the Law, Federal Limitations on State Taxation of Interstate Business, 75 HARv. L. REv. 953, 957 (1962) [hereinafter cited as.Developments].

68. U.S. ConsT. amend. XIV, \&1. See supra note 62.

69. See supra text accompanying notes 49-54.

70. The Court in Commonwealth Edison, in addition to equating the first and fourth prongs of Complete Auto Transit, see supra notes 49-54 and accompanying text, concluded that "there is no requirement under the Due Process Clause that the amount of general review taxes collected from a particular activity must be reasonably related to the value of the services provided to the activity." 453 U.S. at 622 . Thus, deference to the states" "considerable latitude in imposing general revenue taxes," $i d$., requires a limited degree of judicial scrutiny when that tax is challenged under the due process clause - a substantive due process standard. See supra text accompanying note 50. Substantive due process requires only that a tax be rationally related to a legitimate government end. J. NowaK, supra note 3, at 410 . Again, this approach ignores the distinct nature of due process and commerce clause concerns. See supra text accompanying gotes 61-68. The interpretation of the fourth prong advocated in this note would require a closer relationship between taxes and legitunate government purposes than the "rationally related" standard; if the state can establish this relationship, substantive due process is a fortiori satisfied.

71. International Shoe Co. v. Washington, 326 U.S. 310, 316, 319-20 (1945). See Hanson v. Denckla, 357 U.S. 235251 (1958); Madere, supra note 4, at 119.

72. 430 U.S. at 279. See supra text accompanying note 33. 
Auto Transit's third and fourth prongs, if properly interpreted, would adequately protect commerce clause interests by directing that a tax must "not discriminate against interstate commerce, and [inust be] fairly related to services provided by the State." 73 The Court in Commonwealth Edison incorrectly subordinated commerce clause concerns to those of the due process clause by concluding that the fourth prong has no significance independent of the first prong when applied to inost state taxes. ${ }^{74}$

\section{B. The Case Law Basis of the Complete Auto Transit Test}

Since the early 1900's the Supreme Court has recognized a limited exception to the then general rule prohibiting state taxation of interstate commerce, reasoning that "[e]ven interstate busmess must pay its way."75 Subsequent decisions analyzing commerce clause restraints expressly adopted this exception and emphasized the Court's concern with equity and fairness in the taxing process. The Court in Western Live Stock v. Bureau of Revenue ordered interstate commerce to pay its "just share of state tax burden," that "[s]tate taxation falling on interstate commerce . . . can only be justified as designed to make such commerce bear a fair share of the cost of the local government whose protection it enjoys."77 From these cases establishing the states' limited right to tax evolved the broader doctrine of Complete Auto Transit, ${ }^{78}$ a doctrine rooted in fairness.

Unfortunately, the Court in Commonwealth Edison disregarded its previous equity concerns. In determining the nature of review required under the fourth prong of Complete Auto Transit, the Commonwealth Edison Court seemed content to argne semantics, deciding that com-

73. 430 U.S. at 279.

74. Commonwealth Edison Co. v. Montana, 453 U.S. at 625-26. The fourth prong now has independent significance only "in those cases involving highway use taxes and similar levies designated as charges for specific state services." W. Hellerstein, First Use Tax, supra note 4, at 617. See infra text accompanying notes 83-86.

75. Postal Tel.-Cable Co. v. City of Richmond, 249 U.S. 252, 259 (1919). See supra notes 26. 27 and accompanying text.

76. 303 U.S. 250,254 (1938) (emphasis added).

77. 329 U.S. 249, 253 (1946) (emphasis added). See General Motors Corp. v. Washimgton, 377 U.S. 436, 440-41 (1964).

78. Note that Complete Auto Transit and subsequent opinions demonstrate an important shift in the perspective from which the Supreme Court views state taxes on interstate commerce. The Court's general rule once was that these taxes are constitutional only in himited and specified circumstances. See supra text accompanying notes 21-27. Complete Auto Transit reversed the presumption underlying the general rule by permitting taxes on interstate commerce except in certain circumstances. This was a strong concession to the states' rights to tax. If the commerce clause is to retain any vitality in this area, the Court must use caution when establishing rules, as in Commonwealth Edison, defining the circumstances under which a tax is invalid. 
merce bears a "just or fair share" if the tax imposed is related merely to the taxpayer's contact with the state, regardless of the actual amount of the taxes levied. ${ }^{79}$ Although it pays lip service to fairness, the Court's conclusion is a triumph of form over substance. A state legislature can easily design a tax that establishes the Commonwealth Edison relationship to services provided, but taxes at an unconscionably high rate. ${ }^{80}$ Legislative gymnastics of this kind are precisely what the Court sought to avoid in Complete Auto Transit. ${ }^{81}$

The common meaning of the language advocating equity and fairness, as used by the Supreme Court prior to Commonwealth Edison, mdicates that a proper review of a state tax on interstate commerce must consider the actual tax burden borne by the taxpayer or, conversely, the amount of revenues received by the taxing state. In addition, the Court's approach to issues closely related to those presented by the fourth prong illustrates more concretely its awareness of the significance of the actual quantitative burden on a taxpayer involved in interstate commerce. The second prong of the Complete Auto Transit test requires that a tax be "fairly apportioned" to survive a constitutional challenge. In establishing this eleinent, the Court expressly sought to minimize the undesirable effects of multiple taxation, that is, taxation by several states of the same income earned by an interstate taxpayer. ${ }^{82}$ Apparently, the Court recognized that such a situation could easily become so onerous as to be debilitating. Yet as a practical matter, a single excessive tax can be as burdensoine to the interstate taxpayer as several taxes on the same income. Although inultiple taxation is primarily a due process issue, it does not require a great logical step to conclude that commerce, as well as due process, suffers when tax burdens become oppressive.

79. 453 U.S. at 623-24.

80. "Under the Court's reasoning any ad valorem tax will satisfy the fourth prong; indeed, the Court implicitly ratifies Montana's contention that it is free to tax this coal at $100 \%$ or even $1000 \%$ of value should it clioose to do so." 453 U.S. at 645-46 (Blackmun, J., dissenting).

81. See supra text accompanying notes $20-37$ and accompanying text.

82. Moorman Mfg. Co. v. Bair, 437 U.S. 267, 272-73 (1978); Complete Auto Transit, Inc. v. Brady, 430 U.S. at 282. See Mobil Oil Corp. v. Cornmissioner of Taxes, 445 U.S. 425, 444 (1980); Western Live Stock v. Bureau of Revenue, 303 U.S. 250, 257 (1938); Madere, supra note 4, at 12123.

The second prong derives from the requirements of due process, which are separate from those of the commerce clause. See supra notes $60-68$ and accompanying text. The concern is that the tax should reacli only that income earned froin some minimum contact with the taxing state. The argument made in the text accoinpanying this footnote is advanced only to show the Supreme Cour's recognition of problems stemming from burdensome taxes affecting interstate commerce. It is not suggested that multiple taxation concerns are identical to those of the fourth prong. 
Even stronger evidence of the Supreme Court's concern with the quantitative limits on state taxation is the its approach to state taxes levied on a nonresident's use of particular public facilities - user taxes. ${ }^{83}$ The Supreme Court has made it clear that a user tax is vahd only if it is related to the cost to the state of the benefit provided to the taxpayer:

[W]hile state or local tolls must reflect a "uniform, fair and practical standard" relating to public expenditures, it is the amount of the tax, not its formula, that is of central concern. At least so long as the toll is based on some fair approximation of use or privilege for use . . . and is . . . [not] excessive in comparison with the governmental benefit conferred, it will pass constitutional muster . . . ${ }^{84}$

There is no reason to limit this standard of review to user taxes. Admittedly, user taxes are im some ways distmguishable from privilege and severance taxes. The costs associated with the use of a particular facility that depreciates at a predictable rate are easier to calculate than are costs related to the provision of "police and fire protection, the benefits of a tramed work force, and the advantages of a civilized society." ${ }^{25}$ Indeed, it may be more accurate to categorize the user tax as a "rent charged by the State, based on its proprietary interest in the public property, rather than a tax." 86 Yet these distinctions do not justify different standards of judicial review. They address only administrative concerns - the valuation of costs and the determination that tax revenues are in fact spent on the maintenance of specific facilities rather than constitutional distimctions.

83. A "user" tax, as defined in this section, should be distinguished from "compensatory use" taxes. The former is levied on the nonresiden's use of facilities within the taxing state; the latter are imposed on the "use, storage, withdrawal or consumption of tangible personal property within the borders of the taxing jurisdiction" when such property would otherwise escape taxation. P. Hartman, Federal Limitations on State and Local Taxation 578 (1981). See generally; id. at 577-638, 665-74.

The most commonly taxed uses include public highways, e.g., Clark v. Paul Gray, lnc., 306 U.S. 583 (1939); Ingels v. Morf, 300 U.S. 290 (1937), and airports, e.g., Evansville-Vanderburgh Airport Auth. Dist. v. Delta Airlines, Inc., 405 U.S. 707 (1972). See P. HARTMAN, supra, at 669, nn. 25-33.

84. 405 U.S. at 716-17 (emphasis added). See P. HARTMan, supra note 83, at 670.

85. Japan Lime v. County of Los Angeles, 441 U.S. 434, 445 (1979). See supra text accompanying note 40.

86. P. HaRtman, supra note 83 , at 665 . One may legitimately argue that a severance tax, such as the one at issue in Commonwealth Edison, is as similar to a rent as is a user tax and thus deserves an equivalent standard of judicial review. Indeed, any tax desigued to recover the benefits of a civilized society may be reasonably considered a payment of rent for the use of those benefits. The Supreme Court was content to accept without question, however, the Montana Supreme Court's characterization of the severence tax at issue as a "general revenue" tax, not a "user" tax. 453 U.S. at 621-22. See supra note 49. Although debatable, this conclusion is not dispositive. The analysis which follows apphies to any type of tax levied under the circumstances noted. 
The Supreme Court, therefore, requires coordination between the value of benefits provided and the amount of taxes paid only when such amounts are quantifiable with relative ease and precision. This has led to arbitrary distinctions between the kind of taxes levied for the purpose of constitutional review. ${ }^{87}$ Yet, under certain circumstances, practical considerations might warrant deference to state legislatures' or Congress's ability to reasonably restrain states' power to tax ${ }^{88}$ In the case of taxation of energy-producing resources moved in interstate commerce, however, deference is improper. The Court has underestimated the importance of judicial review in this area, in light of legislative ineffectiveness. ${ }^{89}$ Additionally, the Court has overestimated the difficulties of a factual inquiry into the value of services provided. As a result, the Court has mistakenly refused to require that taxes be "fairly related" to the value of services provided.

\section{Judicial Deference to State and Federal Legislatures}

In adopting a standard of review, a court is influenced both by the legal issues involved and by the practical difficulties of resolving those issues. ${ }^{90}$ This note has sought to demonstrate the absence of an adequate theoretical basis for limitimg judicial review of state taxes affecting interstate commerce to a perfunctory determination that the tax is fairly related to the taxpayers' contact with the taxing state. Practical considerations are equally important, however, and deference to state legislatures or Congress is appropriate in some instances. ${ }^{91}$ Judicial deference is improper, however, when legislatures are ill-equipped to resolve the issue or have demonstrated an unwillingness to do so. Such is the case in a narrow but significant subset of state taxation of interstate commerce - taxes levied on energy-producing natural resources.

1. Ineffectiveness of State Legislation. The Supreme Court in Commonwealth Edison concluded that, even apart from the difficulties of judicial factfinding and subjective determinations, the proper level of taxation is best left to our two-step political process, which allows state legislatures to control local taxation subject to overriding federal legislation action. ${ }^{92}$ Admittedly, this process works well in certain circumstances. However, energy-producing natural resources generally

87. See generally P. HARTMAN, supra note 83, at 665-75.

88. See infra note 91 and accompanying text.

89. See infra notes 92-107 and accompanying text.

90. See generally J. NowAK, supra note 3, at 24-110.

91. For example, "[p]rominent on the surface of any case held to involve a pohtical question is found . . . a lack of judicially discoverable and manageable standards for resolving it . . . " Baker v. Carr, 369 U.S. 186, 217 (1962).

92. 453 U.S. at 628. See supra notes 55-57 accompanying text. 
share two critically important characteristics that make state legislation an meffective means of protecting commerce clause rights: (1) the resources are located within limited geographic areas, and (2) nonresidents consume vastly greater amounts of the resource than do residents. ${ }^{93}$ The confluence of these factors removes the economic and pohitical incentives for self-restraint by the states, leading to excessive taxes at the expense of interstate commerce.

Basic free-market economic theory suggests that market forces will react to an increased state tax by encouraging production in another state, if all other factors remaim constant. 94 Thus, assuming that the tax is the only distortion of an otherwise purely competitive market, the tax will drive taxpayers away from the taxing state, generally to the disadvantage of that state.95 Ideally, coinpetitive market forces would himit state tax rates. Unfortunately, energy-producing resources are not collected and distributed in a market that even approaches the purely competitive ideal. Rather, the limited geographic locations of energyproducing resources ${ }^{96}$ such as coal, oil, and natural gas, give disproportionate market power to resource-rich states, allowing a taxing state to act as the monopolistic owner of the resource. ${ }^{97}$ The state can thus tax at a much higher rate than it could in a competitive inarket because producers must operate within the state possessing the resource. ${ }^{98}$

93. See 453 U.S. at 639 (Blackmun, J., dissenting) (as much as $90 \%$ of the coal mined in Montana is exported).

94. See supra note 67.

95. The state will lose tax revenues, jobs for its residents and such imtangibles as good will, publicity and reputation within the business community.

96. It also may be the case that the resource can be found in many locations, but the quahity of the resource is so varied that production is prohibitively expensive in all but a few locations.

97. Resources may be located within a specific region that encoinpasses several states, instead of a single state. This circumstance, not surprisingly, usually produces an oligopoly situation because of the prevalence of "tax leadership": surrounding states tend to follow one state's tax increases. "Tax leadership' in the western states appears to be an emerging reahity. . . . '[T]ax leadership' within soine limits [antitrust] among these states can hardly be prevented." Churcll, Conficting Federal, State and Local Interest Trends in State and Local Energy Taxation, Coal and Copper - A Case in Point, 31 NaT'L TAX J. 269, 278 (1978).

98. A legitimate dispute exists as to who actually bears the incidence of such taxes. It has been argued that the state, as land owner, bears the burden in the long run. See McClure, Economic Constraints on State and Local Taxation of Energy Resources, 31 NAT'L TAX J. 257, 259 (1978). While this conclusion may be valid, it is apparent that producers and consumers suffer the tax mcidence in the short run. The short run is "short" however, only when compared to the long run, which is likely to be long indeed. Energy production is a capital-mtensive, relatively immobile industry. The result is slow movement between states and a relatively inclastic response to fluctuations in the cost of production. As a cousequence, interstate commerce suffers substantially froin the excessive tax, even if ouly for the "short run." See Sager, The Supreme Court, 1980 Term, 95 HARV. L. REV. 17, 107-08 (1981). 
Even so, the political process of the taxing state would operate to repeal such an onerous tax if the burden were born by those with political influence, i.e., resident voters. However, it is more often true that nonresidents are the primary consumers of the resource.99 They can exert at best only indirect pressure on the state to lower rates, usually without success. ${ }^{100}$ It is true that some of the tax incidence will fall on voters as resident energy consumers and producers. Political pressure from the electorate will be dampened, however, by the benefits of the enormous tax-generated revenue enjoyed by the state and its residents. ${ }^{101}$ Agam, the result is an absence of adequate checks on the tax rate. Rather, there are financial incentives to impose excessive taxes on resources moved in interstate commerce. The only political alternative is an appeal to Congress to restrain states' taxing power.

2. Ineffectiveness of Federal Legislation. Theoretically, when state taxes on interstate commerce become excessive, the political process will limit the states' taxing power via federal legislation initiated by voter protest. ${ }^{102}$ The political machinery is cumbersolne, ${ }^{103}$ however, and can be further slowed by pressure exerted on Congress by the states themselves. Both the Supreine Court and commentators have noted Congress's unwillingness to act on a variety of issues relating to state taxation of interstate commerce. ${ }^{104}$ In addition, legislation often may

99. See supra note 93 and accompanying text.

100. "To the extent that the tax burden falls on economic interests outside the taxing State, it is not likely to be alleviated by those political restraints which are normally exerted on legislation which adversely affects interests within the taxing State." P. HartMan, supra note 83 at 8 . See Link, supra note 5, at 263, 267-68 Developments, supra note 67, at 957, 969.

Although nonresident producers can indirectly affect state decisions, for example, through political contributions, their influence is almost certainly less than that of the unuch larger group of state residents who enjoy the benefits of high taxes on energy-producing resources. See supra note 6 and infro note 101 and accompanying text.

101. See supra note 6 and accompanying text. See generally Church, supra note 97; Link, supra note 5.

102. See Commonwcalth Edison Co. v. Montana, 453 U.S. 609, 628 (1981).

103. Even matters of such national importance and urgency as federal fiscal policies (e.g., the adjustment of a particular tax rate) apparently suffer from excessive "administrative lags" (the length of time between initial consideration in Congress and legislative response). That lag has been estimated at as much as 15 months and is primarily the result of "congressional log rolling and pressure groups." T. CARGILl, Money, The Financial System, and Monetary Policy 472-73 (1979). There is no reason to expect less delay when Congress tries to resolve issues relating to the proper taxation of interstate commerce, given the inyriad of local interests and the complex factfinding required.

104. See, e.g., Mobil Oil Corp. v. Commissioner of Taxes, 445 U.S. $425,448-49$ (1980); J. Hellerstein, supra note 4, at 351; W. Hellerstein, First Use Tax, supra note 4, at 619, n.93; W. Hellerstem, State Taxation of Interstate Business and the Supreme Court, 1974 Term: Standard Pressed Steel and Colomal Pipeline, 62 VA. L. Rev. 149, 153 (1976). 
be so much the product of political compromise that it is ineffective or merely a stop-gap measure. ${ }^{105}$

Furthermore, a ceiling on the state tax rate, would not necessarily solve the problems. States can easily circumvent such legislation through carefully worded statutes. ${ }^{106}$ Implementation of the federal law would be hampered by the inevitable inyriad of legal questions regarding the scope of the federal legislation, the scope of the state tax, the effective rate of the tax, the type of tax being limited (income tax, severence tax, use tax, property tax, etc.) and other bothersome issues. The judiciary would not escape difficult factual inquiries into state legislative histories or vague subjective determinations that promote inconsistencies. Finally, an inflexible ceiling would create inequities among states with differing resource-related costs, and where those costs exceed the ceiling rate, states would bear costs properly attributable to nonresidents. ${ }^{107}$ Thus, deference to the federal political process will not protect interstate commerce from excessive taxation, protect the courts from difficult determinations relating those taxes, or protect states from inequitable tax burdens. Federal legislation, like state legislation, is ill-suited to respond effectively to these issues. The judiciary must bear the responsibility.

3. The Courts' Duty to Review State Taxes. The Supreme Court has recognized a general duty of the courts to review the constitutionality of state taxes on interstate commerce. As early as 1919 the Court stated that "the authority [is] in the courts, on proper apphication, to determine whether . . . the charge made is reasonably proportionate to the service to be rendered and the habilities involved."108 Several subsequent decisions have recognized this judicial duty to scrutinize potentially unconstitutional state taxes on interstate commerce, rather than defer to Congress. ${ }^{109}$

105. See J. Hellerstein, supra note 4 , at 340.

106. See supra notes 28-29 and accompanying text.

107. Note, Commerce Clause Restraints on State Taxation of Energy Resources: A Suggested Framework for Analysis, 60 WASH. U.L.Q. 425, 456-57 (1982).

108. Postal Tel.-Cable Co. v. City of Richmond, 249 U.S. 252, 260 (1919).

109. "[Congress] generally has left the determination to the courts of what state taxes on or affecting commerce were permissible and what impermissible under the Commerce Clause." Meinphis Natural Gas Co. v. Stone, 335 U.S. 80, 85 (1948).

Some have thought that the wisest course would be for this Court to uphold all state taxes not patently discriminatory, and wait for Congress to adjust conflicts when and as it wished. But this view has not prevailed, and the Court has therefore been forced to decide in many yaried factual situations whether the application of a given state tax to a given aspect of interstate activity violates the Commerce Clause.

Michigan-Wisconsin Pipe Lime Co. v. Calvert, 347 U.S. 157, 166 (1954). See Mobil Oil Corp. v. Commissioner of Taxes, 445 U.S. 425, 447 (1980). Cf. Wisconsin v. J.C. Penney Co., 311 U.S. 435, 445 (1940). 
The Court, therefore, has noted the importance of judicial review in addressing subissues of the general area of state taxation - due process, fair apportionment, multiple taxation, and privilege taxes.10 There is no compelling reason not to subject fourth-prong questions to similar judicial scrutiny. The political process is not an inherently better inethod of balancing a state's right to tax the fundainental protections of the commerce clause, and may in fact be worse. 111 The dangers of state-imposed trade restraints make it incumbent on the courts, as referees, to ensure a reasonable balance.

\section{A Proposed Standard of Judicial Review}

The preceding discussion suggests the pitfalls of depending on state and federal legislatures to prevent excessive state taxes on energyproducing resources moved in interstate commerce. ${ }^{112}$ Yet in Commonwealth Edison, the Suprene Court deferred to the political process not only because of its presumed superiority to the judiciary in this area, but also because of the Court's reluctance to engage in labyrinthian factfinding designed to "calculate acceptable rates or levels of taxation." 113 It is indeed unreasonable to require courts to wade through reams of data and testimony to arrive at a proper tax rate for every challenged tax. Such inquiries would undoubtedly lead to arbitrary and inconsistent results, while court dockets would become intolerably congested; deference to the superior factinding skills of a legislative body would be both preferrable and necessary. However, such extensive judicial inquiry is neither constitutionally mandated, nor suggested by legal precedent. In fact, a much more manageable review will protect commerce clause rights without exceeding the judiciary's factfinding capabilities.

\section{A. Approximating the Correlation between Taxes Paid and Benefits Provided}

The language of the fourth prong itself suggests that taxes paid need not exactly equal the cost of services provided by the taxing state. Taxes must inerely be "fairly related" to the services enjoyed by the taxpayer. ${ }^{14}$ Hence, there need only be an ascertainable "relationship," and that relationship must be one which "fairly" burdens the taxpayer;

110. See supra note 109.

111. See supra notes $92-107$ and accompanying text.

112. See supra notes $90-111$ and accompanying text.

113. 453 U.S. at 628.

114. Complete Auto Transit, Inc. v. Brady, 430 U.S. 274, 279 (1977). See supra text accompanying note 33 . 
only approximation, not mathematical precision, is called for. The Supreme Court has approved similar approximations when considering various issues within the general area of state taxation of interstate commerce. ${ }^{115}$ In Commonwealth Edison the Court misperceived the degree of scrutimy necessary for adequate review; it misjudged the precision required and overestimated the requisite amount of judicial factfinding. This led the Court to conclude that it could not devise a legal test that would both accurately reflect the numerous considerations involved in establishing a proper tax rate and mamtain the necessary degree of flexibility. ${ }^{116}$ The Court incorrectly viewed the task as one of determining the fair tax rate. Instead, the Court need only have determined whether the state einployed good faith efforts and reasonable computations to arrive at the tax rate imposed - a decidedly more manageable standard of review.

\section{B. Irrebuttable Presumption of Fair Relationship}

The guarantee of free trade inherent in the commerce clause is inadequately protected when judicial review is denied those state taxes whose incidence falls on goods (1) inoved in imterstate commerce, (2) used primarily by nonresidents of the taxing state, and (3) subject to monopoly-like control by that state. ${ }^{117}$ If the goods are not moved interstate, no commerce clause question arises; if the tax primarily burdens state residents, the state's own political process will militate against excessive taxes; if the state lacks monopoly-like control of the good, competitive market forces will compel a reasonably mobile industry to seek a more favorable economic chinate in a lower-tax state, to the disadvantage of the taxing state. Absent one of these enumerated elements, therefore, the judiciary may properly assume that the state has set a reasonable tax rate; the scales should tilt in favor of the state's right to tax and against commerce clause concerns.

A party challenging the validity of a tax on commerce clause grounds, therefore, must establish all three elements before proceeding with his case. Failure to prove this prima facie case leads to an irrebuttable presumption that the challenged tax is indeed "fairly related to

115. See Japan Line v. County of Los Angeles, 441 U.S. 434, 455 (1979) (considering fair apportionment of taxes); Evansville-Vanderburgh Airport Auth. Dist. v. Delta Airlines Inc., 405 U.S. 707, 716-17 (1972) (considering user taxes); Capitol Greyhound Lines v. Brice, 339 U.S. 542 , 546 (1950); International Harvester Co. v. Evatt, 329 U.S. 416, 422-23 (1947); Northwest Airlines Inc., v. Minnesota, 322 U.S. 292, 325 (1944) (Stone, C.J., dissenting); Clark v. Paul Gray, Inc., 306 U.S. 583, 599 (1939); J. Hellerstein, supra note 4, at 347; W. Hellerstein, First Use Tax, supra note 4 at 615 .

116. 453 U.S. at 628. See supra note 55 and accompanying text.

117. See supro notes $93-101$ and accompanying text. 
the services provided," and the suit should be dismissed. No questions of excessiveness or calculations of values are considered by the court. Furthermore, forcing the taxpayer to bear this heavy burden of production will protect the defendant states and the judicial system from a deluge of meritless suits challenging a variety of state taxes and the concomitant time-consuming factual inquiries. ${ }^{118}$ The courts nay thus defer to the political process on most tax challenges, reviewing only those taxes most likely to infringe commerce clause rights.

\section{Palpably Excessive Taxes}

If the taxpayer meets his burden of production, he then may attempt to show that the challenged tax is so excessive in relation to the costs incurred by the state that free trade is unduly restricted. This stage of the proceedings admittedly involves a degree of the valuation process that the Supreme Court sought to avoid in Commonwealth Edison. ${ }^{119}$ It should again be noted, however, that rough approximations are sufficient at this poimt. The Court need not sift through voluminous evidence to decide which party's calculations are correct. Even if the taxpayer succeeds in showing that the taxes paid appear palpably in excess of the value of services provided, the burden of production simply shifts to the state. The court has not been requested to establish a proper tax rate or even accept as conclusive the calculations offered by the parties. It must decide only whether there exists sufficient evidence that the tax levied might be thought unfair. If the taxpayer fails to create this doubt, he has not met his burden of proof, and the tax inust be upheld as constitutional.

\section{The State's Burden of Proof}

If the taxpayer convinces the court that the challenged tax might be excessive, the state inust then shoulder the burden of proving that the process used to establish the tax rate and the costs considered were likely to result in a proper tax levy. The court need not becone immersed in the feared battle of numbers, with each side liurling subjective valuations and expert testimony at the other. Rather, the state need merely present evidence of a colorable, good-faith attempt to levy a tax designed to cover the costs actually incurred by the state in pro-

118. Many challenges would be summarily resolved in favor of the state at this stage of the proceedings, with minimal burden on the courts or cost to the states themselves. The majority of those that remain would probably involve taxes on energy resources.

119. See supra note 55 and accompanying text. However, for a model outlining the compensable services associated with severance taxes, see Note, An Outline for Development of Cost-Based State Severance Taxes, 20 NaT. ResouRCES J. 913 (1980). 
viding services to the taxpayer. ${ }^{120}$ If the state proves this to the court's satisfaction, the mandates of the commerce clause are met. It is true that much latitude must be accorded to those cost valuations reflecting "the advantages of a civilized society." 121 Yet, the court's concern is with distinguishing good-faith valuations from attempts to subvert the restraints of the commerce clause. The scrutimy, therefore, would be of the process leading to the challenged result, not the result itself. If that process is reasonably likely to reimburse the state only for the value of the services provided, it is constitutional. The court would, in effect, defer to the political process, reviewing taxes only to the extent necessary to prevent commerce clause violations when that process is ineffective. ${ }^{122}$ Furthermore, the nature of this review would in practice allow courts to invalidate only those taxes well in excess of the value of services provided.

\section{ConClusion}

The states' taxing power must be restramed to preserve a fair relationship between taxes paid and the value of the services the state provides. A state's own political system usually provides adequate

120. Consideration of the "services" for which a state may levy a:compensating tax is beyond the scope of this note. Yet, one particular service, if allowed, poses valuation problems because it is not readily quantifiable, and therefore, warrants brief mention. The Supreme Court justified the severance tax in Commonwealth Edison because "mining of the coal depletes the resource base and wealth of the State, thereby diminishing a future source of taxes and economic activity." 453 U.S. at 624 (footnote omitted). Admittedly, this calculation adds ambiguity to the valuation process and gives states more discretion in choosing a tax rate. Even so, the standard of review advocated in this note should make the difficulty surmountable. See supra text accompanying notes 119-20.

There are, however, two reasons why such a loss of wealth nnay not be compensable, despite the Court's statement. First, the depletion of the state's wealth is not a "service provided," as the Supreme Court has used the phrase in post-Complete Auto Transit decisions. Second, a tax designed to compensate the state for such a loss would "serve only to advance 'simple economic protectionism' " and would thus violate the commerce clause. New England Power Co. v. New Hampshire, 102 S.Ct. 1096, 1101 (1982). See Hughes v. Oklahoma, 441 U.S. 322 (1979); City of Philadelphia v. New Jersey, 437 U.S. 617 (1978); Foster-Fountain Packing Co. v. Haydel, 278 U.S. 1 (1928); Pennsylvania v. West Virginia, 262 U.S. 553 (1923); West v. Kansas Natural Gas Co., 221 U.S. 229 (1911). Although New England Power concerned a state regulation prohibiting export of the state's resource, the rationale applies to taxes as well. A tax that compensates for lost wealth is the functional equivalent of a regulation restricting export. In either case, the taxing state has unconstitutionally hoarded a natural resource. See Note, The Effect and Validity of State Taxation of Energy Resources, 58 WASH. U.L.Q. 345, 357 (1980).

121. See supra note $\mathbf{4 0}$ and accompanying text.

122. The proposed standard of judicial review is similar in many respects to the review currently given laws governing economic or social welfare when challenged on substantive due process grounds. Under the substantive due process standard, the state must only show that the law bears a rational relation to the end it is designed to achieve. See Railway Express Agency, Inc. v. New York, 336 U.S. 106 (1949); J. Nowak supra note 3, at 408. See also supra note 70. 
controls, thus creating a presumption that taxes are fair and equitable vis-à-vis state expenses. Yet political processes, both state and federal, are generally ineffective safeguards when the challenged tax directly or indirectly burdens energy-producing natural resources.

Although state taxes on energy resources constitute a small percentage of the total number of state taxes levied, their impact can be significant when the resources move in interstate commerce, are used primarily by nonresidents of the taxing state, and are subject to monopoly-like control by that state. ${ }^{123}$ The impact intensifies if states are permitted to tax at will, restrained only by the formalistic requirement that taxes relate to the taxpayer's contact with the taxing state. Taxpayers and interstate commerce are then at the mercy of states with fortuitous inonopohistic control over resources consumed primarily outside the state. Although interstate commerce inust pay its own way, ${ }^{124}$ equity and the implicit mandate of the commerce clause require that interstate commerce not pay more than its just share.

In Commonwealth Edison Co. v. Montana the Supreme Court overlooked the inherent shortcomings of the political process and the relative ease with whicl courts can conduct an adequate review. The courts should accept their responsibility to maintain a reasonable balance between the states' right to tax and the nation's interest in unfettered trade. The courts, therefore, inust require that taxes on energyproducing resources moved in interstate commerce be fairly related to the state's cost of providing legitimate services. To adopt a lesser standard is to demote free trade to a status beneath that intended by the drafters of the commerce clause, to the detriment of the nation as a whole.

123. See supra note 6 and accompanying text.

124. See supra notes 26-27 and accompanying text. 